\title{
STUDI HERMENEUTIKA PENGENDALIAN INTERN PEMBERIAN KREDIT BADAN USAHA MILIK DESA (BUMDes)
}

\author{
Jumaiyah ${ }^{1 *}$; Aulia Fanandia Mawardiani ${ }^{2}$ \\ ${ }_{1,2}^{2}$ Universitas Islam Nahdlatul Ulama Jepara \\ *Korespondensi : jumaiyaha@gmail.com
}

\begin{abstract}
Internal control is the spirit of BUMDes success. Therefore, the security of lending should be considered. The purpose of this study was to find out how the internal control in BUMDes Giri Samudra in Jambu Village Mlonggo Sub-district of Jepara Regency. The research method used qualitative with deep hermeneutical approach to understand the forms of communication symbols by the BUMDes at the time of granting credit. The results of research that has been done indicate the existence of internal control in crediting system at BUMDes Giri Samudra Desa Jambu not apply Internal regulation with maximum
\end{abstract}

Keywords: Hermeneutics, BUMDes, Internal Control, Credit Granting.

\begin{abstract}
ABSTRAK
Pengendalian internal merupakan ruh dari suksesnya lajunya BUMDes. Oleh karnanya keamanan atas pemberian kredit harus diperhatikan. Tujuan penelitian ini untuk mengetahui bagaimana penerapan pengendalian internal di BUMDes Giri Samudra di Desa Jambu Kecamatan Mlonggo Kabupaten Jepara. Metode penelitian yang digunakan kualitatif dengan pendekatan hermeneutika mendalam untuk memahami bentuk-bentuk symbol komunikasi oleh pihak BUMDes pada saat pemberian kredit. Hasil penelitian yang telah dilakukan menunjukkan bahwa pengendalian internal dalam sistem pemberian kredit pada BUMDes Giri Samudra Desa Jambu belum menerapkan pengendalian internal dengan maksimal.
\end{abstract}

Kata Kunci : Hermeneutika, BUMDes, Pengendalian Internal, Pemberian Kredit.

\section{PENDAHULUAN}

Dalam rangka ketahanan pangan warga Indonesia dan untuk mngurangi urbanisasi yaitu perpindahan penduduk dari desa ke kota pemerintah mengeluarkan Undang-Undang Nomor 4 Tahun 2014 Tentang Desa. pasal 4 point d bahwa peraturan Desa bertujuan mendorong prakarsa, gerakan, dan partisipasi masyarakat Desa untuk pengembangan potensi dan Aset Desa guna kesejahteraan bersama. Dengan adanya peraturan itu diharapkan Desa mampu mandiri mengelola asset yang dimiliki Desa. Untuk kemandirian Desa dalam pengelolaan asset Desa, pemerintah mengeluarkan peraturan lewat menteri Desa, pembangunan daerah tertinggal, dan transmigrasi republik Indonesia nomor 4 tahun 2015 tentang pendirian, pengurusan dan pengelolaan, dan pembubaran badan usaha milik desa. dalam peraturan itu pasal 1 ayat 2 menjelaskan Badan Usaha Milik Desa, selanjutnya disebut BUM Desa, adalah badan usaha yang seluruh atau sebagian besar modalnya dimiliki oleh Desa melalui penyertaan secara langsung yang berasal dari kekayaan Desa yang dipisahkan guna mengelola aset, jasa pelayanan, dan usaha lainnya untuk sebesarbesarnya kesejahteraan masyarakat Desa. 
Didirikanya BUMDes pemerintah mengharapkan menemukan trobosan baru dalam mengentas kemiskinan, pengangguran serta urbanisasi. Setiap BUMDes di beri wewenang untuk mendirikan badan usaha. Badan usaha yang banyak didirikan bergerak dalam simpan pinjam seperti BUMDes yang ada di Desa Jambu Kecamatan Mlonggo Kabupaten Jepara. Perkembangan usaha simpan pinjam saat ini berjalan dengan sangat pesatnya, hal ini bertujuan untuk mengentaskan kemiskinan. Berbagai bentuk program pengembangan ekonomi dipedesaan sudah sejak lama dijalankan oleh pemerintah, namun upaya tersebut belum membuahkan hasil yang memuaskan. Terdapat banyak faktor yang menyebabkan kurang berhasilnya program-program tersebut, diantaranya yaitu karena campur tangan pemerintah yang sangat besar akibatnya justru menghambat daya kreatifitas dan inovasi masyarakat desa dalam menjalankan roda perekonomian desa. Belajar dari pengalaman masalalu, satu pendekatan yang diharapkan mampu menggerakkan roda perekonomian dan kemandirian di suatu desa adalah melalui pendirian kelembagaan ekonomi yang sepenuhnya dikelola oleh masyarakat desa itu sendiri. Usaha ini bergerak dalam bidang pertanian, peternakan, penyaluran dan peminjaman dana kepada masyarakat yang membutuhkan untuk mengembangkan usahanya, dan Lembaga ini memang didirikan atas dasar instruksi dari pemerintah. Supaya adanya lembaga ini tidak dikuasai oleh kelompok tertentu, maka kepemilikan lembaga itu oleh desa dan di kelola bersama dimana tujuan nantinya akan meningkatkan Pendapatan Asli Desa (PADes) (Atmadja A. t., 2014) .

Desa Jambu Kecamatan Mlonggo Kabupaten Jepara Badan Usaha Milik Desa memilih simpan pinjam. Untuk Menghindari terjadinya penyimpangan atau untuk menjamin pengembalian kredit oleh peminjam atau nasabah dibutuhkan suatu sistem pengendalian intern kredit yang mana tujuannya yaitu untuk mengecek ketelitian dalam menggulirkan dana pinjaman dan menjaga pengelolaan kekayaan serta dapat mendorong efisiensi untuk mematuhi kebijakan yang ditetapkan oleh pihak manajemen. Pemberian kredit harus diberikan dengan hati-hati untuk menghindari terjadinya kredit macet. Sistem pengendalian intern dan $5 \mathrm{c}$ adalah beberapa dari banyak cara yang bisa dilakukan oleh pengelola untuk menentukan pemberian kredit dan pencegahan terjadinya kredit macet ( Wiradana, dkk, 2015).

(Mulyadi, 2016) mengatakan bahwa pengendalian intern meliputi struktur organisasi, metode dan ukuran-ukuran yang dikoordinasikan untuk menjaga aset organisasi, mengecek ketelitian dan keandalan data akuntansi, mendorong efisiensi dan mendorong dipatuhinya kebijakan manajemen. Tujuan dari sistem pengendalian internal adalah sebagai berikut: (1) menjaga aset organisasi, (2) megecek ketelitian dan keandalan data akuntansi, (3) mendorong efisiensi (4) mendorong dipatuhinya kebijkan manajemen. Jadi sistem pengendalian intern sangat berperan dalam keadaan ini, dengan sistem pengendalian intern yang memadai kejadian atau keadaan yang tidak diharapkan seperti kecurangan atau kredit macet akan sangat kecil kemungkinannya terjadi, dimana dalam memberikan suatu kredit akan ada penilaian-penilaian 
yang memadai untuk mengurangi terjadinya resiko penyimpangan atau penyelewengan di masa yang akan datang.

Berdasarkan paparan pada latar belakang yang telah dijelaskan peneltian ini di beri judul : "Studi Hermeneutika Pengendalian Intern Pemberian Kredit Badan Usaha Milik Desa (BUMDes)"

\section{TINJAUAN PUSTAKA}

\subsection{Pengendalian Intern}

Pengendalian internal sangat di butuhkan dalam menjalankan sebuah usaha dengan harapan usaha yang dijalankan menjadi sustainable sebagaimana yang di jelaskan oleh American Institute of Carified Publik Accountants (AICPA) bahwa Pengendalian internal mencakup segala rencana organisasi dan semua metode serta tindakan yang telah digunakan dalam suatu perusahaan untuk mengamankan aktivanya, mengecek keandalan dan kecermatan data akuntansi, memajukan efisiensi operasi, mendorong ketaatan pada kebijakan yang telah ditetapkan (James Hall , 2009). Lain halnya dengan Mulyadi (2016) menjelaskan bahwa sistem pengendalian intern meliputi struktur organisasi, metode dan ukuran-ukuran yang dikoordinasikan untuk menjaga kekayaan organisasi, mengecek ketelitian dan keandalan data akuntansi, mendorong efisiensi dan mendorong dipatuhinya kebijakan manajemen. Pengendalian intern merupakan suatu proses untuk mencapai tujuan tertentu, namun pengendalian intern bukanlah suatu tujuan, tetapi merupakan bagian yang tidak terpisahkan. Penjelasan ini dipertajam oleh Hartanto (1997) dalam (Mardi, 2011) bahwa pengendalian internal dengan membedakan dalam arti yang sempit, dan dalam arti yang luas. Dalam arti sempit, pengendalian internal disamakan dengan internal check yang merupakan mekanisme pemeriksaan ketelitian data administrasi. Akan tetapi dalam arti luas, pengendalian internal disamakan dengan management control, yaitu suatu sistem yang meliputi semua cara yang digunakan oleh pimpinan perusahaan untuk mengawasi dan mengendalikan perusahaan.

Jadi Pengendalian Internal merupakan suatu sistem yang meliputi struktur organisasi beserta semua mekanisme dan ukuran-ukuran yang dipatuhi bersama untuk menjaga seluruh harta kekayaan organisasi dari berbagai arah (Mardi, 2011). Hal ini diperlukan untuk mengatur dan mengarahkan aktifitas- aktifitas suatu lembaga keuangan atau perusahaan. Pengendalian internal bukanlah suatu tujuan namun berupa rangkaian tindakan bersifat pervasif dan menjadi bagian yang tidak dapat terpisahkan, bukan hanya sebagai tambahan dari infrastruktur suatu entitas namun diharapkan mampu memberikan keyakinan memadai bukan keyakinan mutlak.

\subsection{Unsur Sistem Pengendalian Internal}


Pengendalian internal harus tercipta secara kondusif seperti yang di paparkan oleh Mardi (2011) Agar suatu sistem pengendalian intenal dapat berjalan secara efektif seperti yang diharapkan, harus memiliki unsur pokok sistem pengendalian internal adalah sebagai berikut:

\section{Struktur Organisasi}

Merupakan suatu kerangka pemisahan tanggung jawab secara tegas berdasarkan fungsi dan tingkatan unit yang dibentuk. Prinsip dalam menyusun struktur oranisasi, yaitu pemisahan antara setiap fungsi yang ada dan suatu fungsi jangan diberi tanggungjawab penuh melaksanakan semua tahapan kegiatan, hal ini bertujuan supaya tercipta mekanisme saling mengendalikan antar fungsi secara maksimal. Jadi struktur organisasi merupakan suatu pemisahan tugas antar bagian agar tidak ada rangkap jabatan.

2.Sistem wewenang dan prosedur pencatatan dalam organisasi.

Struktur organisasi harus dilengkapi dengan uraian tugas yang mengatur hak dan wewenang masing-masing tingkatan beserta seluruh jajarannya. Jadi setiap karyawan harus tahu hak dan kewajiban serta tanggungjawab masing-masing bagian. Prosedur pencatatan yang baik menjamin ketelitian dan keandalan data dalam perusahaan.

3.Pelaksanaan kerja secara sehat.

Tata cara kerja secara sehat merupakan pelaksanaan yag dibuat sedemikian rupa untuk mendukung tercapainya tujuan pengendalian internal yang ditunjukkan dalam beberapa cara. Unsur kehati hatian dan rolling pegawai sangat penting untuk dijaga.

4.Pegawai berkualitas.

Salah satu unsur pokok yang menjadi penggerak organisasi ialah karyawan, karyawan harus berkualitas agar organisasi memiliki citra yang berkualitas. Secara umum, kualitas karyawan ditentukan oleh 3 aspek yaitu, pendidikan, pengalaman dan akhlak. Tidak hanya berkualitas namun kesesuaian tanggung jawab dan pembagian tugas perlu diperhatikan

\subsection{Struktur Pengendalian Internal}

Pengendalian internal akan berjalan dengan baik jika di tunjang dengan Struktur pengendalian internal yang meliputi berbagai kebijakan dan prosedur yang ditetapkan guna memberikan arah yang jelas dan benar untuk pencapaian tujuan organisasi dimasa yang akan datang. Sebagaimana yang diungkapkan (Bodnar, 2010) suatu prosedur yang dirancang untuk memastikan bahwa elemen proses pengendalian internal diimplementasikan dalam suatu sistem aplikasi tertentu di setiap siklus transaksi organisasi yaitu pengendalian pemrosesan transakasi. Pengendalian pemrosesan transakasi mencakup pengendalian umum dan pengendalian aplikasi.

a. Pengendalian umum

Pengendalian umum mempengaruhi semua pemrosesan transaksi dan mencakup beberapa hal (1) Perencanaan organisasi pemrosesan data. (2) Prosedur operasi secara umum. (3) Karakteristik pengendalian peralatan. (4) Pengendalian akses data dan peralatan 


\section{b.Pengendalian aplikasi}

Pengendalian aplikasi merupakan pengendalian yang spesifik untuk satu aplikasi tertentu. Pengendalian aplikasi dikelompokkan menjadi dua (a) Pengendalian input, Dirancang untuk mencegah serta mendeteksi kesalahan pada tahap penginputan data. (b) Pengendalian Proses, dirancang untuk memberikan keyakinan bahwa pemrosesan telah terjadi sesuai dengan spesifikasi yang ditetapkan dan bahwa tidak ada transaksi yang terlewat yang tidak diproses atau bahwa tidak ada transaksi tambahan yang mestinya tidak ikut diproses . (c) Pengendalian Output, pengendalian ini dirancang untuk memastikan bahwa input dan proses pengendalian yang telah dijalankan menghasilkan output yang valid dan bahwa output telah didistribusikan secara tepat.

\subsection{Komponen Pengendalian Intenal}

Komponen pengendalian internal sangat dipengaruhi oleh kejadian atau hubungan antar masing-masing komponen dalam sistem pengendalian internal. Menurut (Romney \& Steinbart, 2014) Terdapat lima komponen sistem pengendalian internal, yaitu sebagai berikut:

1) Lingkungan Internal (Internal environment)

Lingkungan internal atau budaya perusahaan, mempengaruhi cara suatu lembaga organisasi menetapkan strategi dan tujuannya, membuat struktur aktfitas bisnis dan mengidentifikasi, menilai, serta merespon risiko yang terjadi. Karena inti dari suatu entitas adalah manusinya yang meliputi nilai etika, intregitas, dan kompetensi. Hal ini adalah fondasi dari seluruh komponen ERM lainnya. Lingkungan internal yang lemah sering kali menghasilkan kerusakan didalam manajemen dan pengendalian risiko. Sebuah lingkungan internal mencakup (a) Filisofi Manajemen, gaya pengoperasian, dan risiko. (b) Komitmen terhadap suatu integritas, nilai-nilai etis, dan kompetensi. (c) Pengawasan pengendalian internal oleh dewan direksi. (d) Struktur organisasi.(e) Metode penetapan wewenang dan tanggung jawab. (f) Standart-standart sumber daya manusia yang menarik, dapat mengembangkan, dan mempertahankan individu yang kompeten. (g) Pengaruh eksternal.

2) Penilaian Risiko dan Respons Risiko

Untuk mencapai tujuan manajemen penilaian resiko dan respon resiko Manajemen harus mengidentifikasi dan menganalisis risiko untuk menentukan bagaimana cara risikorisiko seharusnya dikelola. Manajemen juga harus mengidentifikasi dan menilai perubahanperubahan yang dapat secara signifikan berdampak pada sistem pengendalian internal. Menurut (Romney \& Steinbart, 2014) manajemen dapat merespons risiko dengan salah satu dari empat cara 1) Mengurangi, Maksudnya adalah mengurangi segala kemungkinan dan dampak risiko dengan mengimplementasikan sistem pengendalian internal yang efektif. 2) Menerima, menerima kemungkinan dan dampak risiko. 3) Membagikan, membagikan risiko atau mentrasfer kepada orang lain dengan asuransi, mengalihdayakan sebuah aktifitas, atau 
masuk kedalam transaksi lindung nilai (hegdging). 4) Menghindari, menghindari segala risiko dengan tidak melakukan aktivitas yang menciptakan risiko. Pendapat ini sejalan dengan Para akuntan dan perancang sistem membantu manajemen dalam merancang sistem pengendalian yang efektif untuk mengurangi risiko bawaan. Mereka juga mengevaluasi sistem pengendalian internal untuk memastikan bahwa sistem yang dirancang tersebut beroperasi dengan efektif. Mereka menilai dan mengurangi risiko menggunakan starategi penilaian dan respon risiko. Langkah pertama yang harus dilakukan adalah identifikasi kejadian berikut:
a. Memperkirakan kemungkinan dan dampak
b. Mengidentifikasi pengendalian
c. Memperkirakan biaya dan manfaat
d. Menentukan efektifitas biaya/ manfaat
e. Mengimplementasikan pengendalian atau menerima, membagi, atau menghindari risiko.

\subsection{Kredit}

Kredit merupakan pengalihan kepemilikan asset dari badan usaha kepada perorangan sebagaimana yang diuatrakan (Ismail, 2013) kredit merupakan dana dari pihak pemilik dana kepada pihak yang memerlukan dana. Penyaluran dana tersebut didasarkan pada asas kepercayaan yang diberikan oleh pemilik dana kepada pengguna dana tersebut. Sementara itu Undang-Undang Perbankan No.10 tahun 1998 mengartikan kredit agak berbeda yaitu sebagai penyedia uang atau tagihan yang dapat dipersamakan dengan itu, berdasarkan persetujuan atau kesepakatan pinjam meminjam antara bank dan pihak lain yang mewajibkan pihak peminjam untuk melunasi utangnya setelah jangka waktu tertentu dengan pemberian bunga. Devinisi kredit menurut undang-undang jauh berbeda dengan yang di ungkapkan oleh (Drs. OP. Simorangkir, 2011), kredit adalah sebuah pemberian prestasi (misalnya berupa uang atau barang) dengan balas prestasi yang akan terjadi pada waktu yang akan datang. Namun demikian perbedaan pemaknaan kredit tidak menghilangkan arti yang sebenarnya dari kredit tersebut yaitu memberikan sebuah pinjaman kepada pihak lain dengan perjanjian yang sebelumnya di sepakati bersama.

\section{METODE}

Metode penelitian yang digunakan kualitatif dengan pendekatan hermeneutika. Hermeneutika merupakan proses mengubah sesuatu atau situasi ketidaktahuan menjadi mengerti (E. Sumaryono, 2013). Dalam hal ini bagaimana pihak BUMDes memberikan kredit pada nasabahnya, apakah sudah menerapkan pengendalian internal atau belum? Instrument kunci dari penelitian ini adalah pengurus BUMDes dan pihak manajemen BUMDes yang mengeluarkan kebijakan procedural kredit dalam hal ini adalah direktur BUMdes, Bendahara BUMDes serta KA.Unit Usaha simpan pinjam. 


\subsection{Metode Pengumpulan Data}

Pengumpulan data yang dilakukan dengan menggunakan tiga metode yaitu

1) Metode Interview (Wawancara)

Dalam hal penelitian ini yang di interview adalah informan kunci yaitu pemegang kebijakan BUMDes seperti direktur, sekretaris, bendahara dan ka- Unit simpan pinjam. Dilain pihak interview dilakukan kepada peminjam dana. Interview dilakukan kerangka memahami secara mendalam makna dari komunikasi yang telah dilakukan pihak pemberi kredit dan yang menerima kredit.

2) Metode Observasi

Observasi yang dilakukan adalah mengamati apa yang terjadi ketika pemberian kredit serta pengembalian kredit dan bagaimana proses pengendalian untuk menekan adanya kredit macet. Inti dari observasi adalah adanya perilaku yang tampak dan adanya tujuan yang ingin dicapai. Perilaku yang tampak dapat berupa perilaku yang dapat dilihat langsung oleh mata, dapat didengar, dapat dihitung, dan dapat diukur (Sugiyono, 2014). Dalam hal ini peneliti menggunakan metode observasi non partisipan, peneliti tidak terlibat dengan kegiatan seharihari orang yang sedang diamati atau yang digunakan sebagi sumber data penelitian dan hanya sebagi pengamat independen.

3) Metode Dokumentasi

Metode dokumentasi adalah dokumen sebagai bahan klasik untuk meneliti perkembangan historis yang khusus, dan biasanya digunakan untuk menjawab beberapa persoalan tentang apa, kapan. Dimana. Data-data tersebut dapat berupa arsip-arsip yang digunakan untuk memperjelas sistem pengendalian intern pemberian kredit (Sugiyono, 2014).

\subsection{Metode Analisis Data}

Analisis data didalam penelitian ini yaitu menggunakan metode analisis deskriptif kualitatif dengan pendekatan hermeneutic. Cara yang digunakan data yang diperoleh dari observasi, wawancara dan dokumentasi direduksi atau di sortir, data yang di ambil merupakan data yang paling penting untuk mendukung olah data. Sementara data yang kurang penting di buang. Data yang mendukung penelitian di sajikan kemudian di tarik kesimpulan (Maryaeni,2012). ${ }^{1}$

\section{HASIL DAN PEMBAHASAN}

\subsection{Prosedur Pemberian kredit Pada BUMDes Giri Samudra}

Prosesn pengajuan kredit BUMDes ini masih tergolong sederhana, dalam proses pemberian kredit mereka belum sepenuhnya sesuai dengan system pengendalian. Pengurus 
BUMDes Giri Samudra belum mengetahui tugas dan tanggung jawab Prinsip-Prinsip pemberian kredit seperti seharusnya analisa kredit dilakukan oleh staff khusus analis kredit. Hal ini diperkuat dengan hasil wawancara yang telah dilakukan dengan Direktur BUMDes yaitu Bapak Muchlisin mulai dari beberapa proses yang yang dilalui sampai kredit itu dicairkan. Beliau mengatakan bahwa prosedur pemberian kredit adalah sebagai berikut:

R1: Prosedurnya itu Anggota datang langsung ke BUMDes dengan membawa identitas diri beserta jaminan tetapi kalau yang menjadi jaminan adalah sawah kreditur tidak perlu membawa jaminan. Kemudian nasabah atau anggota mengisi surat permohonan kredit dan diajukan ke direktur, setelah direktur menyetujui lalu diserahkan ke bendahara, bendahara melakukan survey, terus kalau oke di acc sama pak bendahara dan direktur diteruskan ke KA. Unit simpan simpan untuk diotorisasi dan diserahkan lagi ke admin baru kredit bisa dicairkan ke yang mengajukan kredit. ( direkam pada hari Rabu, Pukul 09.00 WIB 1 Maret 2017)

Hal serupa juga dikatakan oleh KA. Unit Simpan Pinjam Bapak Sunarto. Beliau mengakatan:

R3: Anggota datang langsung ke BUMDes dengan membawa identitas diri beserta jaminan entah itu motor, tanah, dll. Kemudian nasabah harus mengisi surat permohonan kredit dan diajukan ke direktur lalu diserahkan ke bendahara, terus kalau disetujui sama bagian bendahara dan direktur diserahkan ke saya, atas sepengetahuan dan otorisasi dari direktur dan bendahara laporan itu saya tandangani dan diteruskan ke admin baru kredit bisa dicairkan ke yang mengajukan kredit. (direkam pada hari Kamis, Pukul 09.00 WIB 1 Maret 2017)

Dari kutipan wawancara diatas, dapat dilihat bahwa prosedur pemberian kredit yang ada di BUMDes Giri Samudra itu sederhana dan mudah. Pemohon langsung datang ke kantor BUMDes dengan mengisi surat permohonan kredit. Lalu surat permohonan di serahkan ke direktur, bendahara melakukan survey, jika bendahara dan direktur sudah mengotorisasi dan menyetujui maka dilanjutkan ke KA. Unit Simpan Pinjam untuk ditandatangani dan diserahkan kembali pada admin jika disetujui kredit bisa langsung cair.

Selanjutnya yaitu untuk surat permohonan kredit dan otorisasinya dibuat rangkap dua dan diotorisasi oleh Direksi, Bendahara dan diketahui oleh KA. Unit simpan pinjam. Hal ini sesuai dengan yang dikatakan oleh Direktur, KA. Unit simpan pinjam dan admin bahwa:

R3: Surat permohonan kredit dibuat rangkap dua, diotorisasi sama bendahara direksi dan ka. Unit simpan pinjam. 
R4: Dibuat rangkap dua, diotorisasi sama bendahara direksi dan ka. Unit simpan pinjam

Jenis kredit yang ditawarkan dan syarat dalam permohonan kredit di BUMDes Giri samudra yaitu syarat Administrasi dan Agunan. Seperti yang dikatakan oleh Direktur dan Bendahara BUMDes

R1 : Ada dua macam, Jangka panjang dan jangka pendek. Lalu untuk Syaratnya adalah syarat administrasi seperti Fotocopy KK (Kartu Keluarga) fotocopy KTP ( Kartu Tanda Penduduk) suami dan istri kalau ada eee.. misale kalau untuk ini modal untuk usaha itu ada agunannya, usaha itu ada agunan tapi kalau untuk sewa sawah itu ndak pake aguna, hanya garapan sawah.

R2 : Ada dua macam, Jangka panjang dan jangka pendek. Lalu untuk Syaratnya adalah Fotocopy kartu keluarga, fotocopy ktp suami dan istri kalau ada eee.. misale kalau untuk ini modal untuk usaha itu ada agunannya, tapi kalau untuk sewa sawah itu ndak pake agunan, hanya garapan sawah biasa yang dipakai

Jawaban yang senada juga diungkapkan oleh Admin BUMDes yang terlukis dalam kutipan wawancara berikut ini:

R4 : Ada dua macam, Jangka panjang dan jangka pendek. Syarat administrasi seperti Fotocopy kk fotocopy ktp suami dan istri kalau ada eee.. misale kalau untuk ini modal untuk usaha itu ada agunannya, usaha itu ada agunan tapi kalau untuk sewa sawah itu ndak pake aguna, hanya garapan sawah. ( Direkam pada Hari kamis Jam 10.00 WIB )

Prosedur pemberian kredit di BUMDes Giri Samudra masih tergolong sederhana, mudah dan kurang efektif. Hanya harga jaminan dan survey yang menentukan jumlah kredit. Seharusnya ada penilaian lain yang benar-benar bisa dijadikan jaminan supaya debitur bisa membayar angsuran. Seperti yang dijelaskan oleh Kasmir (2012) yaitu pada prinsip 5C dan 7P.

BUMDes Giri Samudra selalu memperhatikan beberapa hal sebelum menyalurkan dana kepada anggotanya dan menurut Kasmir ( 2012) ada beberapa kriteria yaitu SIAPA yang meminjam? APAKAH pinjaman aman terhadap resiko? BERAPA jumlah pinjaman? UNTUK maksud apa pinjaman tersebut?

Dalam analisis menggunakan 5C yang paling sering digunakan di dalam BUMDes Giri Samudra adalah jaminan (collateral) dan watak (character) dan capital (modal). Hal pertama 
yang diperhatikan dalam mengajukan kredit pasti jaminan baru setelah itu watak dari calon debitur. Biasanya yang mengajukan kredit adalah anggota BUMDes jadi secara tidak langsung bisa diketahui bagaimana watak dari calon debitur. Lebih jelasnya pihak biasanya pihak BUMDes akan mendatangi ketua RT dan tetangga dekat untuk mencari informasi tentang calon debitur tersebut.

\subsection{Penyebab Kegagalan Kredit dan Cara Mengatasi Kredit Macet}

\subsubsection{Penyebab Kegagalan Kredit}

Sepandai apapun analisa kredit yang dilakukan, kemungkinan terjadinya kredit macet pasti ada. Dalam hal ini penyebab kegagalan yang biasa dihadapi ada dua yaitu:

\section{a. Dari pihak BUMDes}

Misalnya dalam melakukan analisis, pihak bagian kredit kurang teliti sehingga apa yang seharusnya terjadi, tidak diprediksi sebelumnya.

b.Dari pihak nasabah

Dari pihak nasabah sendiri kemacetan kredit dapat terjadi akibat dua hal yaitu:

1) Adanya unsur kesengajaan, dalam hal ini nasabah sengaja untuk tidak bermaksud membayar kewajibanya kepada BUMDes sehingga kredit yang diberikan macet. Dapat dikatakan tidak adanya unsur kemauan untuk membayar.

2) Adanya unsur tidak sengaja. Artinya pihak anggota mau membayar, tetapi tidak mampu. Sebagai contoh kredit yang dibiayai mengalami kerugian atau usahanya sepi dan terkena musibah musibah seperti, kena hama, kebanjiran atau bangkrut. Sehingga kemampuan untuk membayar kredit tidak ada.

Hal ini diperkuat dengan hasil wawancara yang telah dilakukan dengan Direktur dan KA. Unit simpan pinjam. Mulai dari penyebab kegagalan sampai dengan berbagai alasan yang digunakan nasabah untuk tidak membayar. Pada saat diwawancarai Direktur BUMDes menjelaskan:

R1: Pertama, dari pihak kami biasa kurang teliti dalam menganalisa pemberian kredit, sehingga yang seharusnya macet tidak terprediksi oleh kami.

Yang kedua ya karena kenakalan nasabah, biasanya ada nasabah yang memang sengaja tidak mau membayar, padahal seharusnya bisa membayar.

Yang ketiga ya karena nasabah benar-benar tidak mampu membayar karena banyaknya kebutuhan, usahanya sepi atau bangkrut.

\subsubsection{Penyelamatan Kredit}

Penyelamatan terhadap kredit macet Menurut Ismail (2013) dilakukan dengan cara sebagai berikut:

\section{1) Rescheduling}

a. Memperpanjang jangka waktu kredit 
Dalam hal ini kreditur diberikan keringanan dalam masalah jangka waktu kredit misalnya perpanjangan jangka waktu kredit dari 6 bulan menjadi satu tahun sehingga debitur mempunyai waktu lebih lama dalam mengembalikan pinjamannya.

b. Memperpanjang jangka waktu angsuran

Memperpanjang angsuran hampir sama dengan jangka waktu kredit. Dalam hal ini jangka waktu angsuran kredit diperpanjang pembayarannya misalnya dari 36 kali menjadi 48 kali dan hal ini tentu saja jumlah angsuran pun menjadi mengecil seiring dengan penambahan jumlah angsuran.

\section{2) Reconditioning}

Dengan cara mengubah berbagai persyaratan yang ada seperti berikut ini:

a. Penundaan pembayaran bunga sampai jangka waktu tertentu. Dalam hal ini pembayaran bunga sampai waktu tertentu, maksudnya hanya bunga yang dapat ditunda pembayarannya, sedangkan pokok pinjamannya tetap harus dibayar seperti biasa.

b. Penurunan suku bunga Penurunan suku bunga dimaksudkan agar lebih meringankan beban nasabah. Sebagai contoh jika bunga per-tahun sebelumnya dibebankan 20\% diturunkan menjadi $18 \%$, hal ini tergantung dari pertimbangan yang bersangkutan. Penurunan suku bunga dapat mempengaruhi jumlah angsuran yang semakin mengecil sehingga diharapkan dapat membantu meringankan nasabah.

c. Penyitaan jaminan Penyitaan jaminan merupakan jalan terakhir apabila nasabah sudah benar-benar tidak mempunyai etiket baik ataupun sudah tidak mampu lagi untuk membayar semua utang-utangnya.

Sebagai seorang pemimpin Direktur bertanggungjawab secara penuh atas BUMDes termasuk resiko yang terjadi dimasa depan karena keputusan atau kebijakan yang diambilnya. Dalam wawancara yang dilakukan di BUMDes Giri Samudra beliau mengatakan:

R1: Pertama kita datangi orang tersebut, terus diberi surat peringatan, selain itu kita melakukan pendekatan secara kekeluargaan, saya memberikan dia masukan supaya mau membayar kewajibanya. kedua setelah itu jika memang masih macet kita sarankan untuk datang ke kantor untuk meminta keringanan ke direktur BUMDes, namun jika sudah berbagai cara masih tidak bisa baru kita lakukan eksekusi penyitaan dan pelelangan.

Dari apa yang dijelaskan oleh Direktur BUMDes, sudah terlihat jelas apa yang dilakukan pengelola dalam hal penanganan kredit macet sudah baik namun masih perlu untuk ditingkatkan supaya lebih efektif.

\subsection{Elemen Pengendalian Internal}




\subsubsection{Lingkungan Pengendalian (Control Environmen)}

Menurut (Romney \& Steinbart, 2014) Lingkungan internal atau budaya perusahaan, mempengaruhi cara suatu lembaga atau organisasi menetapkan strategi dan tujuannya, membuat struktur aktfitas bisnis dan mengidentifikasi, menilai, serta merespon risiko yang terjadi. Lingkungan pengendalian di BUMDes ini mencakup sikap para manajemen dan karyawan terhadap pentingnya pengendalian yang ada di organisasi tersebut. Seperti halnya bagian-bagian yang menangani masalah kredit yaitu bagian kredit, manager dan admin. Salah satu faktor yang berpengaruh terhadap lingkungan pengendalian adalah manajemen (manajemen tunggal dalam persekutuan atau manajemen bersama yang sesuai dengan RAT) dan gaya operasi manajemen serta praktik kepersonaliaan. Pada BUMDes Giri Samudra telah mamiliki struktur organisasi termasuk didalamnya wewenang dan tanggungjawab. Pengendalian akan efektif apabila hanya ada satu orang petugas yang bertanggungjawab pada satu tugas, hal ini dimaksudkan agar penelusuran dapat lebih mudah dan pemisahan tanggungjawab sangat perlu dilakukan supaya dapat saling mengevaluasi antar karyawan.

Dari hasil wawancara yang diperoleh dari beberapa subjek yaitu kepada Direktur BUMDes, KA. Unit simpan pinjam dan Admin, bahwa hasil analisis pada lingkungan pengendali umumnya sudah sesuai dengan teori yang ada dan cukup efektif. Dalam melaksanakan proses pemberian kredit, BUMDes telah menerapkan unsur-unsur :

\section{1) Integritas dan Nilai Etika}

Integritas dan nilai etika serta kejujuran dan kedisiplinan pada BUMDes Giri samudra telah diterapkan, hal ini sesuai dengan wawancara yang dilakukan dengan Direktur, Bendahara dan Ka. Unit Simpan Pinjam.

R1: Ya. BUMDes Giri Samudra sebenarnya sudah menerapkan kejujuran dan kedisiplinan secara tertulis. Kedisiplinan dan kejujuran merupakan nilai dasar dari suksesnya suatu tujuan BUMDes, sehingga BUMDes Giri Samudra itu mendapatkan kepercayan dari setiap anggota dan masyarakat mbak.....tentu Kami sudah mengarahkan segenap pengurus dan karyawan untuk selalu bersikap santun/etis dan berintegritas tinggi dalam melayani anggotanya.

R2: Ya mbak, tentu Kami sudah mengarahkan segenap pengurus dan karyawan untuk selalu bersikap santun/etis dan berintegritas tinggi dalam melayani anggotanya,

Ya. BUMDes Giri Samudra sebenarnya sudah menerapkan kejujuran dan kedisiplinan secara tertulis.

R3: Ya, kami sudah mengusahakan agar karyawan selalu bersifat etis. Pada hakekatnya perilaku etis berisi tentang keharusan yang wajib dilaksanakan dan larangan yang harus dihindari sebagai penjabaran pelaksanaan prinsip-prinsip Transparansi, eeee... 
Akuntabilitas, dan apa itu eee... Responsibilitas (pertanggung jawaban), Independensi (kemandirian), dan Fairness (kewajaran).

BUMDes Giri Samudra sudah menetapkan kebijakan tertulis mengenai kejujuran dan kedisiplinan. Kedisiplinan dan kejujuran merupakan nilai dasar dari suksesnya suatu tujuan BUMDes, sehingga BUMDes Giri Samudra itu mendapatkan kepercayan dari setiap anggota dan masyarakat

Dari hasil wawancara tersebut dapat disimpulkan bahwa dengan adanya kebijakan dan peraturan pemberian kredit serta adanya otorisasi oleh pejabat yang berwenang. BUMDes Giri Samudra juga sudah menetapkan kebijkan mengenai kejujuran dan kedisiplinan secara tertulis, selain itu BUMDes juga menuntut semua karyawan untuk selalu bersifat etis dalam melaksanakan tugasnya. Kreditur yang telah ada di daftar blacklist tidak akan mendapatkan pinjaman selama kurun waktu 3 tahun dan hanya bisa meminjam uang kurang lebih Rp. 300.000 sampai dengan Rp. 500.000. BUMDes Giri Samudra juga menerapkan prinsip kejujuran dan bersikap etis kepada setiap anggota.

\section{2) Komitmen terhadap Kompetensi}

BUMDes Giri samudra belum efektif karena tidak memiliki rasa tanggung jawab pada tingkat kecakapan karyawan dalam bekerja sesuai dengan profesinya. Hal ini dapat terlihat dari tidak adanya program training, dilakukan atas dasar komitmen terhadap kompetensi. Pembentukan pengurus juga tidak efektif karena langsung ditunjuk oleh kepala desa tanpa ada persyaratan khusus atau lebih spesifik dan tidak sesuai kompetensi, sehingga SDM nya kurang maksimal.

\section{3) Dewan Direksi dan Komite Kredit}

Dilakukannya Komite Kredit oleh Pejabat Kredit yang bertanggung jawab secara langsung pada Dewan Direksi. Dan setiap sebulan sekali atau 6 bulan sekali selalu dilakukan evaluasi atas wewenang tanggungjawab masing-masing bagian. Dalam wawancara yang dilakukan di BUMDes Giri Samudra Direktur dan Bendahara mengatakan:

R1: Satu bulan sekali atau tiga bulan sekali tim kita, eeee... direktur bendahara sekertaris dan admin, kita mengadakan rapat bersama untuk evaluasi wewenang dan tanggung jawab. Dengan demikian kan kita langsung tau dimana letak kesalahan itu dan bisa langsung cari solusinya sehingga kita bisa lebih berhati hati lagi dalam memberikan kredit.

R2: Biasanya setiap sebulan sekali direktur bendahara sekertaris dan admin mengadakan rapat bersama untuk evaluasi wewenang dan tanggung jawab. Dengan demikian kita langsung tau dimana letak kesalahan dan cari solusinya sehingga kita bisa lebih berhati hati lagi.

\section{4) Filosofi Manajemen dan Gaya Operasi}

Filosofi dalam bidang perkreditan berdiri di atas kepercayaan masyarakat. Oleh karena itu, karyawan BUMDes harus menjaga kepercayaan masyarakat yang telah diberikan kepada 
pihak BUMDes. Dengan kata lain, falsafah manajemen yang dipegang oleh BUMDes Giri Samudra adalah melayani kredit kepada seluruh lapisan masyarakat yang ada di Desa Jambu Kecamatan Mlonggo Kabupaten Jepara. Sedangkan gaya operasi yang diterapkan merupakan suatu tindakan partisipatif, hal ini tercermin dari peletakan perencanaan dan pengendalian ditangan manajemen menengah ke bawah. Maka dapat dikatakan, falsafah manajemen dan gaya operasi yang diterapkan oleh BUMDes Giri Samudra telah memadai.

\section{5) Struktur Organisasi}

Struktur organisasi pada BUMDes Giri Samudra telah disusun dengan baik yang ditandai dengan adanya tugas dari masing-masing fungsi, pembagian di beberapa Unit dan secara tertulis namun masih belum efektif karena masih ada rangkap jabatan dan tidak adanya bagian khusus analisis pinjaman.

\section{6) Pelimpahan Wewenang dan Tanggung Jawab}

Pelimpahan otorisasi dan tanggung jawab pada BUMDes Giri Samudra cukup memadai, terlihat dari adanya pelimpahan tanggung jawab, pendelegasian wewenang serta adanya kebijakan-kebijakan yang dilengkapi tanggung jawab serta pengawasannya melalui peraturanperaturan.

\section{7) Kebijakan dan Pelatihan Sumber Daya Manusia}

Komponen kebijakan dan pelatihan SDM belum diterapkan memadai oleh BUMDes Giri Samudra. Hal ini terbukti dengan tidak adanya sistem penerimaan karyawan, pendidikan dan pelatihan serta mutasi dan promosi jabatan sebagai penghargaan terhadap prestasi karyawan.

\subsection{Aktivitas Pengendalian}

Aktifitas pengendalian merupakan suatu kebijakan, prosedur, dan aturan yang memberikan jaminan memadai bahwa tujuan pengendalian telah dicapai dan respons risiko telah dilakukan, misal dengan selalu mencatat, mengolah, meringkas dan melaporkan secara rinci setiap transaksi suatu entitas. Hasil wawancara mengenai aktifitas pengendalian untuk pengecekan independen dan untuk menguji kesesuaian jumlah pemberian kredit dengan data penerimaan kas yang diterima Dengan mencocokkan Buku Pinjaman Anggota dengan bukti kas dan catatan bendahara BUMDes. Hal ini sesuai dengan yang dikatakan Bendahara dan Admin BUMDes Giri samudra

R2: Dengan mencocokkan Buku Pinjaman Anggota dengan bukti kas dan catatan bendahara BUMDes.

R4: Dengan mencocokkan Buku Pinjaman Anggota dengan bukti kas dan catatan ekstra komtabel bendahara BUMDes.

Kesimpulan dari aktifitas pengendalian yang ada di BUMDes Giri samudra adalah: 
1) Pemisahan tugas yang belum memadai terlihat dari adanya rangkap jabatan yang dilakukan oleh Kepala Desa dan Bendahara namun BUMDes sudah menerapkan pemisahan tugas yang menangani permohonan kredit oleh analis kredit, dan administrasi kredit.

2) Pendelegasian wewenang secara wajar atas transaksi dan aktivitas, dalam hal ini hanya Direktur BUMDes dan Bendahara yang berhak memutuskan permohonan kredit yang harus dipertimbangkan terlebih dahulu atas analisa yang telah dilakukan oleh analis kredit.

3) Dokumen dan catatan yang memadai telah dilakukan oleh BUMDes Giri Samudra, hal ini dapat terlihat dari lengkapnya persyaratan kredit yang diperlukan, sehingga akan terlaksana keseragaman dalam penanganan proses pemberian kredit.

\subsection{Pemantauan (Monitoring)}

Pemantauan terhadap sistem pengendalian intern, apakah sistem yang telah ditetapkan sudah dijalankan sesuai dengan RAT. Pengendalian intern dapat dimonitor dengan baik dengan cara penilaian khusus. Usaha pemantauan yang terakhir dapat dilakukan dengan cara mengamati perilaku karyawan atau tanda-tanda peringatan yang diberikan oleh sistem akuntansi. Pemantauan terhadap semua kegiatan operasional pada BUMDes Giri Samudra ini dilakukan secara langsung oleh tim pengawas, Direktur, dan Bendahara BUMDes kepada karyawan dengan melakukan analisa calon anggota atau peminjam tersebut layak atau tidak untuk menerima pinjaman.

Hasil wawancara yang dilakukan dengan Direktur, Bendahara, KA. Unit Simpan pinjam dan Admin mengenai pemantauan dalam pengendalian internal pemberian kredit bagaimana manajemen mewajibkan untuk semua anggota maupun calon anggota yang telah mengajukan pinjaman terlebih dahulu mengisi formulir pengajuan pinjaman yang sudah dibentuk melalui prosedur sesuai ketentuan BUMDes.

Hal ini diperkuat dengan hasil wawancara yang telah dilakukan dengan Direktur BUMDes yaitu: R1: Anggota yang mengajukan kredit wajib mengisi Formulir Pengajuan Pinjaman

\subsection{Informasi dan Komunikasi (Information and Communication)}

Informasi tentang lingkungan pengendalian yaitu penilaian risiko, prosedur pengendalian dan monitoring. Informasi harus diidentifikasi, diproses, dan dikomunikasikan ke semua karyawan sehingga setiap orang dalam suatu entitas dapat melaksanakan tanggungjawabnya dengan baik. BUMDes Giri samudra tentang informasi calon nasabah didapat dari catatan kredit dan formulir atau dokumen pemberian kredit yang sudah diotorisasi dan di stempel, dicatat dan kemudian dilaporkan kepada masing-masing pihak yang bertanggungjawab.

Dalam wawancara yang telah peneliti lakukan dengan Direktur, Bendahara, K.A. Unit Simpan Pinjam dan admin mereka mengatakan bahwa:

R1: Dicatat di buku pinjaman anggota dan buku catatan pengeluaran uang pada bendahara BUMDes Selalu dikomunikasikan antara fungsi keuangan, fungsi akutansi, sekertaris serta 
bendahara BUMDes. Dan yang mengerjakan laporan keuangan ialah admin dibantu pengurus lain BUMDes.

R2: Dicatat di buku pinjaman anggota dan buku catatan pengeluaran uang pada bendahara BUMDes Selalu dikomunikasikan antara fungsi keuangan,serta bendahara BUMDes. Dan yang mengerjakan laporan keuangan ialah admin BUMDes

R3: Dicatat di buku pinjaman anggota dan buku catatan pengeluaran uang pada bendahara BUMDes Iya tentu kami Selalu mengkomunikasikan antara fungsi keuangan, serta bendahara. Dan yang mengerjakan laporan keuangan ialah Admin dibantu Bendahara dan seluruh pengurus BUMDes

R4: Dicatat di buku pinjaman anggota dan buku catatan pengeluaran uang pada bendahara BUMDes. Selalu dikomunikasikan antara fungsi keuangan, fungsi akutansi dan sekretaris serta bendahara BUMDes. Dan yang mengerjakan laporan keuangan ialah saya dibantu pengurus lain.

Hasil wawancara yang dilakukan dengan Direktur, Bendahara, KA. Unit simpan pinjam dan Admin sudah menunjukkan dan mencatat semua transaksi yang sah dengan mencatat di buku pinjaman anggota dan buku catatan pengeluaran uang pada bendahara BUMDes. Dalam pembuatan laporan keuangan pada BUMDes Giri Samudra selalu dikomunikasikan dengan baik, dan yang mengerjakan laporan keuangan ialah admin dibantu dengan pengurus BUMDes Giri Samudra lainya.

\section{KESIMPULAN}

Berdasarkan hasil penelitian dapat diambil kesimpulan sebagai berikut:

1. Sistem pemberian kredit yang dilaksanakan oleh BUMDes Giri Samudra sudah berjalan kurang efektif karena dalam proses pemberian kredit sudah sesuai prosedur dan perundanganundangan, tetapi juga masih banyak yang perlu dibenahi seperti prosedur pemberian kredit yang ada di BUMDes Giri Samudra itu terlalu sederhana dan mudah, hanya harga jaminan, watak dan modal yang dibuat untuk menganalisa kredit selain itu juga seharusnya yang melakukan survey dan analis adalah staf lain bukan Bendahara.

2. Penerapan prosedur Dalam pemberian kredit umum kepada nasabah BUMDes didukung oleh penerapan sistem pengendalian internal yang kurang efektif.

a. Dalam Unsur Pengendalian sudah ada struktur organisasi tetapi tidak efektif dan sistem wewenang yang jelas namun dalam pelaksanaan kerja yang sehat dan pegawai berkualitas masih kurang efektif karena tidak ada rolling pegawai dan pegawai yang ditunjuk tidak sesuai dengan kompetensi jadi SDM nya kurang maksimal.

b. Dalam Komponen Pengendalian sistem pengendalian kredit pada BUMDes Giri Samudra berlangsung kurang efektif dan masih ada beberapa point yang perlu dibenahi kembali Hal ini dibuktikan pada hasil wawancara yang terdiri dari lima komponen Roomney 
\& Steinbart, yaitu pada lingkungan pengendalian tidak adanya rasa tanggung jawab pada tingkat kecakapan karyawan karena tidak adanya program training, penaksiran resiko (risk assesment), bisa dilihat dari proses penilaian kredit yang belum ideal, seperti penerapan prinsip 5C dan 7P yang belum sepenuhnya di terapkan dan proses penangan kredit macet, aktivitas pengendalian (control activities) bisa dilihat dari adanya rangkap jabatan yang dilakukan oleh Bendahara BUMDes yang menjadi Kepala Desa, informasi dan komunikasi (information and communication), dan pemantauan (monitoring) sudah memadai.

3. Tingkat efektifitas pengendalian intern pemberian kredit di BUMDes Giri Samudra berjalan kurang efektif hal ini dibuktikan dengan hasil wawancara pada unsur pengendalian dan elemen pengendalian, jadi sistem pengendalian pemberian kredit di BUMDes Giri samudra masih kurang ideal dalam menerapkan prinsip pemberian kredit.

\section{SARAN DAN UCAPAN TERIMAKASIH}

Berdasarkan hasil penelitian dan kesimpulan yang telah dikemukakan di atas, maka peneliti memberikan saran, pertama Pada aktivitas pengendalian hendaknya memberikan pemisahan tugas antara masing-masing bagian perkreditan mengingat pencatatan atau analisis kredit sangat peting dan memerlukan ketelitian dalam mengolah dan menganalisnya. Kedua Selalu mengawasi pemberian kredit kepada calon nasabah agar meminimalkan terjadinya penipuan atau kecurangan serta melibatkan asuransi pada kredit yang sedang berjalan. Ketiga Selalu meningkatkan prinsip kehati-hatian dalam menyalurkan kredit kepada calon nasabah serta meningkatkan sistem pengendalian intern agar tidak terjadinya kerugian yang dialami BUMDes Giri Samudra. Keempat Selalu meningkatkan kualitas sumber daya manusia pada BUMDes Giri Samudra dalam menganalisis peyaluran kredit pada calon nasabah guna untuk meminimalkan terjadinya kredit macet serta kecurangan-kecurangan yang dilakukan pihak intern maupun ekstern dengan cara selalu mengevaluasi langkah-langkah penyaluran kredit kepada nasabah dan melakukan survey lapangan yang dilakukan secara berkala untuk melihat kondisi debitur. Kelima Dalam aktivitas pelaksanaan pemberian kredit kepada calon nasabah sebaiknya meningkatkan sosialiasi penggunaan tehnologi informasi baru. Pengerjaan yang dilakukan secara manual memungkinkan akan terjadinya kesalahan-kesalahan, dengan adanya teknologi maka akan membantu pengerjaan dan tercapainya keadaan yang efektif dan efisien. 


\section{DAFTAR PUSTAKA}

Atmadja, A. t. (2014). singaraja: Undiksha. Analisis sistem pengendalian Intern Pemberian Kredit Pada Badan Usaha Milik Desa (BUMDes) Mandala Giri Amertha di Desa Tajun, Vol: 2 No.1.

Bodnar, G. H. (2010). Sistem Informasi Akuntansi. yogyakarta: Andi yogyakarta.

Bungin, B. (2005). Analisis data penelitian kualitatif. Jakarta: PT. Raja Grafindo Persada.

E. Sumaryono. (2013).Hermeneutik, Sebuah Metode Filsafat.Yogyakarta: Kanisius.

Herdiansyah, H. (2014). Metodologi Penelitian Kualitatif. Jakarta: Salemba Humanika.

Ismail. (2013). Manajemen Perbankan. Jakarta: Prenadamedia.

Kasmir. (2012). Dasar Dasar perbankan. Jakarta: PT. Raja Grafindo Persada.

Mandira, G. (2014). Analisis Sistem Pengendalian Intern Pemberian Kredit Pada Badan Usaha Milik Desa (BUMDes) Mandala giri Amerta didesa tajun, volume 2 No.1.

Mardi. (2011). Sistem Informasi Akuntansi . Bogor: Ghalia Indonesia.

Maryaeni. (2012). Metode Penelitian Kebudayaan.Jakarta: PT Bumi Aksara

Muchsin, Ahmadi. 1996. Dasar-dasar Komposisi Bahasa Indonesia. Malang: Yayasan AsahAsih Asuh.

Mulyadi. (2016). Sistem Akuntansi edisi 4. Jakarta: Salemba empat.

Nilawati, n. k. (2016). Sistem Pengendalian Intern Pemberian Pada Badan Usaha Milik Desa (BUMDes) Desa Pengastulan Kecamatan Seririt, Kabupaten Buleleng. Volume 7 No.2.

Nurcholis, H. (2011). Pertumbuhan dan Penyelenggaraan Pemerintah Desa. jakarta: erlangga.

Pirdaus. (2013). Analisis Sistem Pengendalian Intern Pemberian Kredit Pada Badan Usaha Milik Desa (BUMDes) Bina Usaha Desa Kepenuhan Barat, 1-5.

Romney \& Steinbart. (2014). Sistem Informasi Akuntansi Edisi 13. Jakarta: Salemba Empat.

Sanusi, A. (2011). Metode Penelitian Bisnis. Jakarta: Salemba Empat.

Sugiyono. (2014). Memahami Penelitian Kualitatif. Bandung: Cv Alfabeta.

Undang-undang nomor 6 Tahun 2014 tentang Desa

Wiradana, I. G. (2015). Analisis Penerapan Sistem Pengendalian Internal Terhadap Pemberian kredit Di Lembaga Perkreditan Desa , 2015 Volume : 3 No. 1.

Yuniarta, G. A. (2015). Evaluasi sistem Pengendalian Intern Pada Pemberian Kredit di Lembaga Perkreditan Desa (LPD) Sudaji, Volume : 3 No.1. 